\title{
POLITICAL SYSTEM OF THE REPUBLIC OF SERBIA AS A BASE FOR FUTURE GENERATIONS OF INTELLECTUALS
}

\author{
Slobodan Petrović ${ }^{1}$ \\ Andrija Blanuša ${ }^{2}$
}

DOI: https://doi.org/10.31410/ERAZ.2019.35

\begin{abstract}
This work uniquely illustrates the degree of development of the political system of the Republic of Serbia since 2000 to date, with all the disadvantages and advantages. It is especially important because it will give the opportunity of comparative presentation of successful and unsuccessful attempts to reform the Serbian society, economy, culture, in the time of globalization and political legal acclimatization to world trends that are an imperative of the 21st century. The accent will be placed on the achieved level of development of the economy, political culture, social corps of society and culture in general as a unique name of all the nations of the world. It will be especially emphasized how much the Republic of Serbia has progressed today and what are the standards of further life and intellectual development in it, which is of crucial importance for the survival of young people in this region, which are the carriers of all the closest changes and social challenges.
\end{abstract}

Keywords: politics, political system, culture, economy, social status, society, youth.

\section{INTRODUCTION}

$\mathrm{T}$ he political system as the main subject of the politics of philosophy deals with the essential issues in the ontological sense of the political habitat: freedom, equality, man, state, power, revolution, class struggle, law, political culture, political organizations, political relations. The second meaning has an empirical meaning. In this respect, the political system is compared to the ,political order”, ,political regime”, „, constitutional system” (if politics is viewed exclusively in an institutionalized and normative form). To understand the policy, political system and all factors of the political system, it is necessary to know the state as a determinant and the object of the expansion of political ideology. Politics is the essence of social as well as economic relations, and it directly influences the shaping of the social situation in society. The leading German political scientist, university professor and head of the Center for Sociological Research Eferhard Holtmann (Everhard Holtmann) defines the political system as a whole body of state and non-state institutions, rules and procedures that are included in the defined operational framework of the political structure in the current processes of formulating and solving political problems, as well as preparing the implementation of general binding political decisions. What is common to all contemporary political system theorists is the claim that the political system is a complex structural-functional entity based on the interaction of society and the political order. 


\section{POPULATION OF THE REPUBLIC OF SERBIAN}

\section{AS A DETERMINING FACTOR OF DEVELOPMENT OF THE COUNTRY}

According to the 2011 census, the Republic of Serbia has 7.1 million inhabitants.

Table 1. First census results for the Republic of Serbia and the regions

\begin{tabular}{|l|c|c|c|c|c|c|c|}
\cline { 2 - 7 } \multicolumn{1}{c|}{} & $\begin{array}{c}\text { Total } \\
\text { number of } \\
\text { enumerated } \\
\text { persons }\end{array}$ & $\begin{array}{c}\text { Total } \\
\text { number of } \\
\text { inhabitants } \\
\text { 2011. }\end{array}$ & $\begin{array}{c}\text { Total } \\
\text { number of } \\
\text { inhabitants } \\
\text { 2002. }\end{array}$ & $\begin{array}{c}\text { Abso- } \\
\text { lute in- } \\
\text { crease-fall } \\
\text { 2011-2002. }\end{array}$ & $\begin{array}{c}\text { Total num- } \\
\text { ber of per- } \\
\text { sons abroad }\end{array}$ & $\begin{array}{c}\text { Total } \\
\text { number of } \\
\text { households }\end{array}$ & $\begin{array}{c}\text { Total } \\
\text { number of } \\
\text { apartments }\end{array}$ \\
\cline { 2 - 8 } & $\mathbf{( 1 )}$ & $\mathbf{( 2 )}$ & $\mathbf{( 3 )}$ & $\mathbf{( 4 )}$ & $\mathbf{( 5 )}$ & $\mathbf{( 6 )}$ & $\mathbf{( 7 )}$ \\
\hline $\begin{array}{l}\text { Republic of } \\
\text { Serbia }\end{array}$ & 7.565 .761 & 7.120 .666 & 7.498 .001 & -377.335 & 29.4045 & 2.497 .187 & 3.243 .587 \\
\hline $\begin{array}{l}\text { Belgrade } \\
\text { region }\end{array}$ & 1.731 .425 & 1.639 .121 & 1.576 .124 & 62.997 & 41.719 & 604.134 & 739.630 \\
\hline $\begin{array}{l}\text { Region of } \\
\text { Vojvodina }\end{array}$ & 1.995 .679 & 1.916 .889 & 2.031 .992 & -115.103 & 46.031 & 697.437 & 852.229 \\
\hline $\begin{array}{l}\text { Region of } \\
\text { Sumadija } \\
\text { and West- } \\
\text { ern Serbia }\end{array}$ & 2.149 .327 & 2.013 .388 & 2.136 .881 & -123.493 & 98.274 & 665.878 & 902.997 \\
\hline $\begin{array}{l}\text { Regions of } \\
\text { Southern } \\
\text { and Eastern } \\
\text { Serbia }\end{array}$ & 1.689 .330 & 1.551 .268 & 1.753 .004 & -201.736 & 108.021 & 529.738 & 748.731 \\
\hline $\begin{array}{l}\text { Region of } \\
\text { Kosovo and } \\
\text { Metohija }\end{array}$ & $\ldots$ & $\ldots$ & $\ldots$ & $\ldots$ & $\ldots$ & $\ldots$ & $\ldots$ \\
\hline
\end{tabular}

Table 2. Population by sex and age

\begin{tabular}{|ccc|}
\hline & Men & Women \\
\hline 885 & 27.667 & 53.883 \\
\hline $70-84$ & 67.814 & 108.754 \\
\hline $70-74$ & 122.964 & 175.658 \\
\hline $65-69$ & 153.847 & 200.295 \\
\hline $60-64$ & 154.775 & 184.669 \\
\hline $55-59$ & 249.785 & 278.629 \\
\hline $50-54$ & 289.566 & 306.713 \\
\hline $45-49$ & 254.508 & 265.836 \\
\hline $40-44$ & 238.502 & 245.484 \\
\hline $35-39$ & 234.274 & 235.654 \\
\hline $30-34$ & 248.554 & 245.380 \\
\hline $25-29$ & 252.502 & 243.860 \\
\hline $20-24$ & 244.911 & 235.375 \\
\hline $15-19$ & 225.231 & 214.510 \\
\hline $10-14$ & 206.968 & 195.026 \\
\hline $5-9$ & 178.419 & 168.450 \\
\hline $0-4$ & 179.721 & 170.433 \\
\hline
\end{tabular}


Analyzing the spreadsheet of the population census for the Republic of Serbia, we conclude that there is a higher mortality rate than birth rate, which gives negative repercussions on the overall political picture and situation in the country. Based on the data presented in Table 1, we can also conclude that there is no decrease in the population in the Belgrade region, while in all other regions there are. This tells us that in addition to the problem of declining births, we are still struggling with the principle of decentralization, which is a basic feature of the post-communist states.

From Table 2. we can also confirm the already brought conclusion - the average population is analyzed by age which is alarming and that in the Republic of Serbia it is necessary to adopt the Strategy on raising birth rates at the republic level, because such data include the Republic of Serbia in one of four [1] oldest European countries, from the aspect of the average age of the population.

Table 3. Total age pyramid in Serbia according to Population Census 2011

\begin{tabular}{|cc|}
\hline 85 & 81.550 \\
\hline $80-84$ & 176.568 \\
$75-79$ & 298.612 \\
$70-74$ & 354.142 \\
$65-69$ & 339.444 \\
\hline $60-64$ & 528.414 \\
\hline $55-59$ & 596.279 \\
\hline $50-54$ & 520.344 \\
$45-49$ & 483.986 \\
$40-44$ & 469.928 \\
$35-39$ & 493.934 \\
$30-34$ & 496.362 \\
$25-29$ & 480.286 \\
$20-24$ & 439.741 \\
$15-19$ & 401.994 \\
$10-14$ & 346.869 \\
$5-9$ & 350.154 \\
$0-4$ & 328.255 \\
\hline
\end{tabular}

From Table 3. we can conclude that according to the pyramid of the age the highest number of aged people is 55-59, which is certainly confirmed by the research of the European Statistical Office, as well as the fact that in the Republic of Serbia there are only 328255 inhabitants between the ages of 0-4. This data also speaks in favor of urgent adoption of the Strategy for increasing birth rates, because the consequences can be alarming, if such a trend continues. A higher rate of mortality than the birth rate is a safe path to the disappearance of one nation.

\section{LEVEL OF ECONOMIC DEVELOPMENT OF THE COMMUNITY AND POLITICAL CULTURE DEVELOPMENT IN THE REPUBLIC OF SERBIA FROM 2000 UNITIL TODAY}

In 2008, the „European Partnership for Serbia” was adopted, which establishes the priorities for the application for membership in the country and 2009 Serbia is formally implemented. In March 2012, Serbia received the status of candidate for EU membership. In September 2013, the Stabilization and Association Agreement between the EU and Serbia came into force. In line with the decision of the European Council in June 2013 to open accession negotiations with Serbia, in December 2013, the Council adopted the negotiating framework and agreed to hold the first intergovernmental conference with Serbia in January 2014. On January 21, 2014, the First 
Intergovernmental Conference was held, signaling the official start of negotiations on Serbia's accession." [2] The development of the political system was seen through the observation of the elections, along with the dates of their maintenance, as well as the percentage of citizens turning out, since it is important to give an overview of the state of participation of political parties in power, the periodicity of holding elections. The same is a direct indication of the degree of development of the political system of the Republic of Serbia as a parameter for determining the development of the political system in the future.

Taking into account some of the most important factors of economic development, the conclusion will be presented in the form of the influence of economic development on the political system of the Republic of Serbia.

Table 4. Factors of economic development

\begin{tabular}{|ll} 
Factors of Economic Development & Republic of Serbia \\
Gross Domestic Product & real growth 2,8\% [3] \\
\hline National Income Per capita & unavailable \\
\hline Public Debt & 24.451 .162 .212 euros [4] \\
\hline The Employment Rate of the Population & $28,0 \%$ [5] \\
Saving (accumulation) Per Capita & 1,283 euros [6] \\
\hline Volume of Foreign Exchange & growth of $12,8 \%$ [7]
\end{tabular}

„According to the National Employment Service, total employment (including employment from employment records and regular employment) in the first quarter of 2017 was less by $2.1 \%$ of employment in the first quarter of 2016. In the period January-May 2017, total employment was less than the average employment in 2016 by $0.7 \%$, but by $0.9 \%$ above the total employment in the first five months of the previous year. Recruitment from the employment records grows faster than employment from regular employment. In the first five months, employment with records is $4.1 \%$ higher than in the same period in 2016, while it is $2.9 \%$ higher than the average in 2016. In the first five months, employment from regular employment is at the same level as in the same period of 2016, while from the average 2016 it is by 1.6\% lower. Quarterly, on an annual basis, employment from the records grew faster (6.8\%) than employment from regular employment (-4\%), which was not the case in previous years.'[8] Gross domestic product (GDP) shows growth of $2.7 \%$ compared to the previous year. [9]

If we observe the available data, economic development as a factor of influence on the political system of the Republic of Serbia is reflected in the slight steps of GDP growth, as well as the employment rate that is at a higher level than the other Republics with which comparisons are made in this paper. However, this does not mean that the political system is stable, given that there is a high rate of those living on the very border of poverty, as well as a large number of people who have been displaced abroad in search of employment.

An overview of the state of culture and its impact in society can be obtained by monitoring various data, such as the existence of the Ombudsperson, active and registered civil society organizations, the existence of cultural institutions, cinemas, theaters, radio and television stations, libraries, all those institutions and institutions which can enable citizens to declare their right, to apply democracy to action in society, to have a certain activity and to act on the political system. Also, only the interpretation of the nation and the programs broadcast in the media can give an image of the interest and information of the citizens, which implies their participation in the political life. As mentioned in previous chapters, the level of education of the nation, as well 
as investments in science and research, is closely related to culture. Interpretation of different factors can lead to a cross-cutting of a society in one country from the aspect of culture. Society in the modern age, strives for democracy, which marks the full participation of citizens in decision making and the creation of a political system. Culture has a direct connection with all the parameters mentioned in the previous chapters, especially those listed as economic and social. A high economic and social standard would mean that citizens have an umbrella organization dealing with the field of culture, as well as material and other possibilities to be consumers of cultural content. In the case of the Republic of Serbia, the Ministry of Culture and Information, and based on the presented results of the research in this paper, does not give its maximums in operation, which is a consequence of lethargic regime policy.

\section{CONCLUSION}

Youth mobility as the most important factor in creating better business opportunities should definitely be a priority of the National Youth Strategy. Proper implementation of objectives and implementation monitoring depends on the indicators created and the communication of all actors in its creation and implementation. With previous experiences, which should give an answer to the successful implementation of the previously adopted document of the National Strategy for Youth in 2008, which envisaged greater participation of young people in the area of mobility and information, on the basis of the documents read out and the scarce research base, we conclude that we have not seriously dealt with this topic by researching the adherence of the Strategy. The correct indicators and results come from extensive and continuous research on youth mobility as well as implementation of projects in the area aimed at improving it, also related to the share of media and information programs, the use of digital technology by young people in the territory Republic of Serbia.

Such research is almost impossible to achieve. Reports of the Ministry of Youth and Sports are the only relevant documents and those that are available, while it is very difficult to reach the research of other parties and organizations. It is clear that the Ministry has an active role in creating youth policy and that the activities contribute to improving the lives of young people in the Republic of Serbia. The problems that exist, not only in our country, but also in other European areas, relate primarily to the increased number of unemployed young people, which, as a domino effect, spreads to other areas envisaged by the previous Strategy. Insufficient mobility and youth awareness deprives them of their ability to participate actively in foreign programs, as well as acquire the skills necessary for further training and thereby reduce their chances of being competitive in the European labor market, as well as domestic ones, and overall, young people today are resisting their participation in political life and become an antipode of the political system, because the politics as such in Serbia gives rise and directs them in the opposite direction.

Through the implemented Youth Projects and Cooperation with Foreign Partners, the current research has come to the conclusion that the problem of youth mobility is mostly insufficient funds. The great barrier comes from insufficient knowledge of foreign languages, which, because of the impossibility of mobility, student exchanges, travel or volunteer engagement, could not, as a skill, continue to develop, since the opportunities for learning and the practice of a foreign language in our country are still not widespread. Knowledge of young people, in media, by insight into the programming of domestic television stations, clearly shows that we do not have quality educational programs that would give young people new knowledge and provide them with a comparative analysis of the current state and better opportunities in the future. 


\section{REFERENCES}

[1] http://ec.europa.eu/eurostat

[2] European Commission, European Neighbourhood Policy And Enlargement Negotiations https://ec.europa.eu/neighbourhood-enlargement/countries/detailed-country-information/ serbia_en date of access 07. November, 12:17 PM.

[3] Republic of Serbia, Republican Bureau of Statistics http://webrzs.stat.gov.rs/WebSite/Public/PageView.aspx?pKey=2 date of access 09. November 2017, 19:38 PM.

[4] Republic of Serbia, Ministry of Financial Affairs, Department for Public Debt Management: http://www.javnidug.gov.rs/lat/default.asp?P=46 date of access 09. November 2017, 21:03 PM.

[5] Definfo, The database contains official statistical data for monitoring the situation and development in the Republic of Serbia: http://devinfo.stat.gov.rs/SerbiaProfileLauncher/files/ profiles/sr/1/DI_Profil_Republika\%20Srbija_EURSRB.pdf date of access 09. November 2017, 20:40 PM.

[6] Bank Association of Serbia, П.У: http://www.ubs-asb.com/Portals/0/vesti/176/31-12-16.pdf page no. 1, date of access 10.11.2017, 18:06 PM.

[7] Republic of Serbia, Republican Bureau of Statistics: http://www.stat.gov.rs/WebSite/public/PublicationView.aspx?pKey=41\&pLevel=1\&pubType $=2 \&$ pubKey $=4430$ date of access: 09. November y 20:22 PM.

[8] Republic Bureau of Statistics: http://webrzs.stat.gov.rs/WebSite/repository/documents/00/02/54/60/Trendovi_jun_17 WEB.pdf page 24, date of access: 10. November 2017, 17:56 PM.

[9] http://webrzs.stat.gov.rs/WebSite/repository/documents/00/02/37/47/KS10_343_2016_srb_ cir.pdf Republic of Serbia, Republic Bureau of Statistics, date of access: 30.01.2017, y 12.30 PM. 